Wapshott R \& Mallett O (2018) Small and medium-sized enterprise policy: Designed to fail? Environment and Planning C: Politics and Space, 36 (4), pp. 750-772. Copyright (C) The Authors 2017. Reprinted by permission of SAGE Publications.

\title{
Small and medium-sized enterprise policy: Designed to fail?
}

\section{Robert Wapshott, University of Sheffield Oliver Mallett, Newcastle University}

\begin{abstract}
Significant doubts persist over the effectiveness of government policy to increase the numbers or performance of small and medium-sized enterprises in the UK economy. We analyse UK political manifestoes from 1964-2015 to examine the development of SME policy in political discourse. We do this by analysing how the broadly-defined category of 'SME' has been characterised in the manifestoes and assess these characterisations in relation to the empirical evidence base. We highlight three consistent themes in UK political manifestoes during 19642015 where SMEs have been characterised as having the potential for growth, struggling to access finance and being over-burdened by regulation. We argue that homogenising the broad range of businesses represented by the SME category and characterising them in these terms misrepresents them, undermining policies developed in relation to this mischaracterisation.
\end{abstract}

\section{Key words}

SME, policy, politics, growth, finance, regulation 


\section{Introduction}

Enterprise policy constitutes policies aimed at both start-ups (entrepreneurship policies) and existing firms classified as small and medium-sized enterprises (SME policies), with 'virtually all organs of government [having] programs which qualify as either EP or SMEP' (Lundström et al., 2014: 946). Governments intervene in a range of ways, acting as '...a regulator, incentiviser and facilitator, or as a supplier' as well as a supporter of other, non-governmental forms of influence and support (Bennett, 2014: 25). Such interventions have existed for a long time, in the UK at least since the 1930s, gaining significance in political discourse since the 1970s with expenditure rising to £8bn per year (Greene et al., 2007; Hughes, 2008; Richard, 2008). We therefore argue that it is important to examine SME policies and the characterisation of the category 'SME' in political discourse.

Despite significant efforts and expenditure, UK SME policies have often failed to achieve their aims (Bridge, 2010) and persistent doubts surround their necessity and cost effectiveness (Curran, 2000). Evaluations of SME policies have proven challenging (Curran, 2000; Storey, 2005) and have produced mixed results, with government-sponsored evaluations tending to be more positive than independent, academic evaluations (Bridge, 2010; Huggins, 1997). Critical considerations of specific policies have identified problems with displacement and deadweight effects (Curran and Storey, 2002; Nightingale and Coad, 2016; Wren, 1996) as well as a lack of understanding of the challenges identified (Nightingale and Coad, 2016). Researchers have also questioned whether policies are sufficiently coordinated (Huggins and Williams, 2009; Turok, 1997), whether available research evidence is being overlooked in forming policy (Arshed et al., 2014; Curran and Storey, 2002) and whether government ministers and policymakers have sufficient expertise to intervene in timely and relevant ways (Bennett 2008). Reflecting on these criticisms, Blackburn and Schaper (2012) present three persistent challenges to the development of SME policy: a lack of progress due to poor learning from 
previous experience; poor use of the evidence base or rigorous evaluation; and poor collaboration and information sharing between relevant parties.

In this article, we analyse UK political manifestoes from 1964-2015 to examine the development of SME policy in political discourse. We do this by analysing how the broadlydefined category of 'SME' has been characterised by politicians in party manifestoes and assess these characterisations in relation to the empirical evidence base. We highlight three consistent themes in UK political manifestoes during the past 50 years where SMEs have been characterised as having the potential for growth, struggling to access finance and being overburdened by regulation. We argue that homogenising the broad range of businesses represented by the SME category and characterising them in these terms misrepresents them, undermining policies developed in relation to this mischaracterisation. We begin the article by briefly tracing the category of SME and why it is important to understand how this category has come to be characterised.

\section{Categorising SMEs}

To effectively deliver policy, the European Commission has, since 2005, defined SMEs for itself and its member states (including the UK) as enterprises that 'employ fewer than 250 persons; and have either an annual turnover not exceeding EUR 50 million or an annual balance sheet total not exceeding EUR 43 million' (European Commission, 2015: 10). In the UK, where statistics tend to adopt the employment definition (fewer than 250 employees), SMEs have come to represent $99.9 \%$ of private businesses (BIS, 2016). This includes a diverse range of firms in terms of size, age, industry and locality (Cosh and Hughes, 1996; Huggins et al, 2015) and less tangible dimensions such as the firm's relationships with the labour market, management style or available networks (Gilman and Edwards, 2007; Wapshott and Mallett, 2015). While it lacks specificity, the SME category is a way of grouping together firms that, 
until the 1960s, had been relatively ignored in UK politics (Beesley and Wilson, 1981). An important development in addressing this omission was the Bolton Committee.

The Bolton Committee was appointed in 1969 by the Labour government to assess the role of small firms in the UK economy and make recommendations on improving government policy. The Committee adopted the definition of less than 200 employees from its terms of reference for manufacturing firms and 'a series of more or less arbitrary definitions in terms of whatever measures appear appropriate for other trades' due to a lack of comprehensive records (Bolton, 1971: 2). The categorisation of businesses that was reinforced by these definitions has proven influential, with the Committee's findings and recommendations forming 'the bedrock of virtually all [SME] research, analysis and policy making' (Curran and Stanworth, 1982: 3; see also HL Deb 12 February 2003; Kirby, 2004). While SME has become the dominant term, it is often used in UK policymaking interchangeably with 'small business' (NAO, 2006), reflecting the Bolton Committee's aims as differentiating these businesses from large firms.

However, the report was a reflection rather than a cause of the growing political prominence of SMEs that accompanied the retreat of Keynsianism (Nightingale and Coad, 2016) and did not fix a definitive way of categorising SMEs in UK politics. 'SME' is a flexible category that is invariably functional, albeit the general trend has been towards greater simplification, often losing Bolton's attention to sector (Ward and Rhodes, 2014). The specific definition adopted depends on the formulation of particular policies, usually in practical terms of employee numbers or financial turnover (e.g. HL Deb 12 February 2003). Further, the definitions for qualifying criteria can be subject to change, for example in the expansion of Small Firm Employment Subsidy (from a 50 employee limit to 200) or the extension of exemptions from Value-Added Taxation and statutory audit requirements (in terms of turnover). These changes in the SME definition illustrate how it can function as a statistical convenience, representing 
for example the extent of a scheme's funding, rather than the focused targeting of a discrete group of businesses.

Given the heterogeneity and significant changes within the population of businesses categorised as SMEs (Cosh and Hughes, 1996, 1998; Hughes, 2008), it is perhaps surprising that this category should be used as a focus for policy. Nonetheless, the SME category is frequently deployed in political discourse and in policymaking in terms of its rationale, forms of intervention and qualifying criteria. The area of SME policy that has emerged in relation to this categorisation of a loosely gathered collection of businesses has been developed in terms of how they have been characterised and it is this characterisation in UK political discourse and its implications for policymaking that forms our analytical focus.

\section{Characterising SMEs}

The purpose of the Bolton Committee and part of its subsequent influence was in making sense of the economic role of SMEs and developing policy recommendations aimed at them (Fuller, 2003). Committee Chair John Bolton argued that, previously, 'the formulation of industrial policy has inevitably proceeded without adequate knowledge of small firms' (Bolton, 1971: $\mathrm{xv})$. The committee argued that what gives unity and meaning to the category of the small firm is that they have relatively little market share, personalised management and that they tend to lack formal management structures and unions. Subsequent debates around how to characterise SMEs and the challenges they face reflect the ways in which political actors 'compose stories that describe harms and difficulties, attribute them to actions of other individuals or organizations, and thereby claim the right to invoke government power to stop the harm' (Stone, 1989: 282). The characterisation of SMEs, in terms of their distinguishing features and the challenges they are perceived to face, represents a framing of the problem that is taken up 
by politicians and policymakers with powerful implications for the 'overture, process and outcome' of policymaking (Weiss, 1989: 118; see also Rochefort and Cobb, 1993).

As we will discuss, this category and its characterisation has been taken up, developed, revised and renewed by politicians as well as by other political actors. It guides policymaking in terms of identifying how to provide support for these businesses or remove barriers they are perceived to face. The Bolton Report continued to be an important reference point for government reports and white papers (e.g. Burdens on Business, DTI, 1985) but the characterisation of SMEs, as with other areas of policymaking, is malleable (Rochefort and Cobb, 1993) and has shifted with different political contexts, economic challenges and the development of new insights (Weiss, 1989). It is the changing characterisation of SMEs that we seek to analyse in this article to gain insights into the underlying assumptions that underpin SME policies.

Specifically, we analyse political manifestoes to explore how SMEs have been characterised in UK political discourse during the period 1964-2015. If a political manifesto sets out what its authors see as problems and potential policy solutions, once elected on the basis of this manifesto the incoming government is establishing a platform for action. The characterisations of the SME category create the impression of common concerns and challenges, a problem definition that governments then seek to address (Weiss, 1989). Our analysis highlights three significant ways that SMEs are characterised relating to their having the potential for growth, struggling to access funding and being over-burdened by regulation, each of which act as causal stories, creating particular roles for government intervention (Stone, 1989). We draw on the empirical evidence base to challenge these portrayals and argue that, if the businesses homogenised under categories such as SME are significantly mischaracterised then SME policy will continue to be ineffective. 


\section{Methodology: Analysing UK Political Debate on SMEs}

\section{Political manifestoes}

To explore the characterisation of SMEs in UK political discourse, we analyse General Election manifestoes from the period 1964-2015. The inclusion and treatment of topics such as SMEs in political texts are important influences on how they are framed and understood more widely (Atkinson, 2015; Finlayson, 2007). General Election manifestoes represent a significant series of comparable political texts over time and are therefore an important source of understanding how SMEs are characterised (Beesley and Wilson, 1981; Beresford, 2015).

Manifestoes '...consist of statements connoting intentions, emphases, promises, pledges, policies or goals to be activated should that party achieve office' (Bara, 2005: 585). As such, these official statements produced by political parties establish a platform for action if elected and a record against which parties and party leaders can be held to account (Laver and Garry, 2000). Moreover, despite increasing scepticism among electorates over politicians keeping election promises, available evidence suggests that elected parties generally do follow-through on manifesto pledges, especially in Britain's political institutional structure (Bara, 2005; Royed, 1996). The issues featured by manifestoes and the positions taken on those issues are therefore important.

Our period of analysis incorporates each General Election from 1964 to 2015, following Beesley and Wilson (1981), who demonstrate how SME research and policymaking in the UK intensified from the mid-1960s (also see Bennett, 2014; Dannreuther and Perren, 2013; Kirby, 2004). This is not to suggest that SME policy did not exist before this period, see for example discussions in the Macmillan Committee (1931) and the Radcliffe Committee (1959), but rather that it became more prominent after the 1960s. The period 1964-2015 features political parties

of different ideologies operating across a wide range of social and economic contexts 
addressing SMEs in their manifestoes in increasing detail, something we explore in the findings below.

We focus on the three 'mainstream' parties of the period, referred to here as Conservative, Labour and Liberal (the latter encompassing the SDP-Liberal Alliance, 1981, Social \& Liberal Democrats, 1988, and Liberal Democrats, 1989), providing an opportunity to observe areas of consensus, difference and development in how SMEs were characterised over time (Laver and Garry, 2000). Across the 14 General Elections falling within our period of analysis this includes a total of 42 manifestoes. The year of each election is listed in Table 1 together with the title of each manifesto and subheadings relating to sections engaged with SME policy. 


\begin{tabular}{|c|c|c|c|}
\hline Year & Party & Manifesto & Headings related to small firms (section header / sub-heading ) \\
\hline \multirow[t]{3}{*}{1964} & Con & Prosperity with a purpose & - \\
\hline & $\mathrm{Lab}^{\mathrm{b}}$ & The New Britain & Planning the new Britain - A national plan \\
\hline & Lib & Think for yourself & Creating the wealth - Cost of living \\
\hline \multirow[t]{3}{*}{1966} & Con & Action not words & Blueprint for a Parliament - To ensure prosperity with steadier prices \\
\hline & $\mathrm{Lab}^{\mathrm{b}}$ & Time for decision & - \\
\hline & Lib & For all the people & - \\
\hline \multirow[t]{3}{*}{1970} & $\mathrm{Con}^{\mathrm{b}}$ & A better tomorrow & Our Programme - Lower taxes; Industrial progress \\
\hline & Lab & Now Britain's strong... & - \\
\hline & Lib & What a life! & The small business; The independent trader; The farmer and grower \\
\hline \multirow[t]{3}{*}{1974} & Con & Firm action for a fair Britain & Industry, Agriculture, and the Regions \\
\hline & $\mathrm{Lab}^{\mathrm{b}}$ & $\begin{array}{l}\text { Let us work together... - } \\
\text { Labour's way out of the crisis }\end{array}$ & - \\
\hline & Lib & Change the face of Britain & - \\
\hline \multirow[t]{3}{*}{$1974^{\mathrm{a}}$} & Con & Putting Britain first & People and Industry - Small business; The impact of wealth and gifts taxes \\
\hline & $\mathrm{Lab}^{\mathrm{b}}$ & Britain will win with Labour & - \\
\hline & Lib & Why Britain needs Liberal govt. & - \\
\hline \multirow[t]{3}{*}{1979} & $\mathrm{Con}^{\mathrm{b}}$ & General Election manifesto & A more prosperous country - Small businesses \\
\hline & Lab & The Labour way is the better way & Jobs and prosperity \\
\hline & Lib & The real fight is for Britain & Economic and Industrial Reform - More jobs in new industries \\
\hline \multirow[t]{3}{*}{1983} & $\mathrm{Con}^{\mathrm{b}}$ & The challenge of our times & $\begin{array}{l}\text { Encouraging Free Enterprise - More small firms; Improving our } \\
\text { environment - Reviving Britain's cities; public transport }\end{array}$ \\
\hline & Lab & The new hope for Britain & Planning for people - The inner-cities \\
\hline & Lib & Working together for Britain & Government and Industry - New and small businesses \\
\hline \multirow[t]{3}{*}{1987} & $\mathrm{Con}^{\mathrm{b}}$ & The next moves forward & Building Prosperity and Employment - Lower taxes; Creating New Jobs \\
\hline & Lab & Britain will win with Labour & - \\
\hline & Lib & Britain united: the time has come & $\begin{array}{l}\text { Rebuilding British Industry - Backing small business; Industrial investment } \\
\text { bonds; Agriculture; Our longer-term objectives; Protecting and enhancing our } \\
\text { countryside }\end{array}$ \\
\hline \multirow[t]{3}{*}{1992} & $\mathrm{Con}^{\mathrm{b}}$ & The best future for Britain & $\begin{array}{l}\text { The route to lower taxes; Setting the economy free; Small Businesses; } \\
\text { Whitehall \& Westminster; Cities; Wales }\end{array}$ \\
\hline & Lab & $\begin{array}{l}\text { It's time to get Britain working } \\
\text { again }\end{array}$ & $\begin{array}{l}\text { Immediate action for national recovery - Action for industry; Building a } \\
\text { strong economy - We will modernise Britain's industries; We will strengthen } \\
\text { our regional economies; We will abolish the poll tax }\end{array}$ \\
\hline & Lib & Changing Britain for good & $\begin{array}{l}\text { Britain's Prosperity: Public Investment; Private Enterprise - Promoting } \\
\text { enterprise }\end{array}$ \\
\hline 1997 & Con & $\begin{array}{l}\text { You can only be sure with the } \\
\text { Conservatives }\end{array}$ & $\begin{array}{l}\text { Jobs and business - Small businesses - Britain's risk takers; Our Vision for } \\
\text { Britain: } 25 \text { Pledges for the Nation - The enterprise centre of Europe }\end{array}$ \\
\hline
\end{tabular}




\begin{tabular}{|c|c|c|c|}
\hline & $\mathrm{Lab}^{\mathrm{b}}$ & $\begin{array}{l}\text { new Labour because Britain } \\
\text { deserves better }\end{array}$ & $\begin{array}{l}\text { We will help create successful and profitable businesses - Backing small } \\
\text { business; Local economic growth; A sensibly set minimum wage }\end{array}$ \\
\hline & Lib & Make the difference & $\begin{array}{l}\text { Our priorities - Investing in Britain's future; Investing in enterprise; Rural } \\
\text { communities }\end{array}$ \\
\hline \multirow[t]{3}{*}{2001} & Con & Time for common sense & Less regulation \\
\hline & $\mathrm{Lab}^{\mathrm{b}}$ & Ambitions for Britain & Investment and reform; The productivity challenge - staying better off \\
\hline & Lib & Freedom, Justice, Honesty & $\begin{array}{l}\text { Employment and training; Protecting consumers and backing business; } \\
\text { Action for your local community }\end{array}$ \\
\hline \multirow[t]{3}{*}{2005} & Con & It's time for action & Lower taxes (less regulation) \\
\hline & $\mathrm{Lab}^{\mathrm{b}}$ & Britain forward not back & $\begin{array}{l}\text { Supporting enterprise; Competition, planning and regulation; Fostering } \\
\text { entrepreneurship; }\end{array}$ \\
\hline & Lib & The real alternative & $\begin{array}{l}\text { A stable, well-managed economy; Business - Cut the red tape that stops } \\
\text { businesses from growing; Introduce small business rate relief }\end{array}$ \\
\hline \multirow[t]{3}{*}{2010} & $\mathrm{Con}^{\mathrm{b}}$ & $\begin{array}{l}\text { Invitation to join the government } \\
\text { of Britain }\end{array}$ & $\begin{array}{l}\text { Create a safer banking system that serves the needs of the economy; Ensure } \\
\text { macroeconomic stability - ... stop Labour's jobs tax; Get Britain working } \\
\text { again - Boost small business; Encourage enterprise; }\end{array}$ \\
\hline & Lab & A future fair for all & $\begin{array}{l}\text { Building the high-growth economy of the future - Championing an enterprise } \\
\text { economy }\end{array}$ \\
\hline & $\mathrm{Lib}^{\mathrm{b}}$ & Change that works for you & Enabling enterprise that benefits Britain \\
\hline \multirow[t]{3}{*}{2015} & $\mathrm{Con}^{\mathrm{b}}$ & $\begin{array}{l}\text { Strong leadership, a clear } \\
\text { economic plan, a brighter, more } \\
\text { secure future }\end{array}$ & $\begin{array}{l}\text { Our plan of action - We will boost apprenticeships and help you secure a good } \\
\text { job; We will reward entrepreneurship; We will cut red tape, boost start-ups and } \\
\text { small businesses }\end{array}$ \\
\hline & Lab & Britain can be better & $\begin{array}{l}\text { We will build an economy that works for working people - Improving } \\
\text { productivity and a new industrial strategy; Backing small business }\end{array}$ \\
\hline & $\mathrm{Lib}$ & Opportunity for everyone & $\begin{array}{l}\text { Economic and industrial growth; Banking and financial reform; Pride in } \\
\text { creativity; Britain in Europe }\end{array}$ \\
\hline
\end{tabular}

Table 1. UK general election manifestoes.

Two General elections in 1974, a denotes October 1974 election (as opposed to February 1974); ${ }^{b}$ Party elected (2010 Con and Lib governed as a coalition)

\section{Analysing political manifestoes}

Thematic coding was used to analyse each manifesto in terms of SMEs and SME policy. Given the breadth of the category SME and the potential ways in which its use may have changed during the period of analysis we analysed the manifestoes in terms of a range of potential synonyms. In the first instance, each manifesto was searched electronically for the following principal terms (and variants): business; enterprise; entrepreneur; independent trader; new business; own account; self-employed; shopkeeper; small firm; sole trader; and SME. We are not suggesting that these terms are each equivalent to SME but, instead, that these terms relate 
to potential areas of what we are referring to as SME policy (following Lundström et al., 2014, and others) and therefore to the characterisation of the SME category. Sections of text containing one or more of the search terms were analytically coded before each manifesto was re-read in full to check the rigour of the initial analysis and to establish a clearer sense of the context surrounding the mention of SMEs (and related terms) as well as to ensure a broader understanding of the parties' positioning for each General Election.

The inductive analysis identified characterisations of SMEs as having the potential for growth, struggling to access funding and being over-burdened by regulation. In our Findings we discuss the emergence and development of these characterisations. We set aside the additional issue of taxation, specifically its burdensome nature on SMEs because, in this context, it overlaps into the personal finances of the business-owners rather than being concerned with the enterprises per se and we are focused on the characterisation of SMEs. Having identified the key themes, we grounded our analysis through the identification of relevant government policy interventions to addresses concerns that manifestoes contain simply empty talk or rhetoric (Laver and Garry, 2000). We then explored evidence from a range of sources, principally academic literature (including key research projects such as Storey, 1994, the Small Business Research Trust, SBRT no date, and the Centre for Business Research, CBR, e.g. Cosh and Hughes, 1996, 1998, Cosh et al 2009b) to understand whether these characterisations of SMEs are supported empirically. The following section presents the results of our analysis.

\section{Findings}

Our focus on the characterisation of SMEs in political manifestoes inevitably foregrounds SMEs over other aspects of contemporary political debate. In the next section we therefore offer a broad overview of how SMEs have been characterised in General Election manifestoes in relation to political debates and the wider context. In the subsequent three sections, we then 
discuss in greater detail the core characterisations of SMEs as having the potential for growth, struggling to access finance and being over-burdened by regulation.

\section{SMEs in UK political manifestoes}

The approach to industrial strategy in the 1960s continued earlier policies to target full employment by focusing on specific industries and large businesses and, for Labour especially, this meant mergers and acquisitions to develop economies of scale and exploit new technology (Tomlinson, 1994). However, SMEs were appearing on the political agenda in relation to particular sectors, early manifesto mentions including, for example, the 1964 Liberal pledge to protect shopkeepers from discrimination from suppliers.

With the economic challenges of the late 1960s and the beginnings of a significant move away from Keynsianism, SME policy became more prominent following interventions such as, in 1969, the Conservative Political Centre pamphlet 'From Acorns to Oaks' (Weatherill and Cope, 1969) and Labour's appointment of the Bolton Committee. The subsequent Conservative government had established in its 1970 manifesto that it would 'decide the best method of providing advice and encouragement for small businesses in the light of the Bolton Report', arguing that 'Small businesses have had a raw deal from Labour', criticisms echoed by the Liberals. From this point onwards, SMEs are principally characterised in the manifestoes as small, often referred to as 'small businesses', that is, in contrast with larger organisations. This contrast, and the emphasis that SMEs are a distinct grouping, underpins a belief that they have particular needs that politicians can help to address (May and McHugh, 2002; Stone, 1989). This can be seen in the manifestoes where SMEs are addressed by specific policies as well as receiving proposed exemptions, for example from workforce training initiatives (Liberal, 1997). 
The importance of SMEs to the UK economy, and especially the growth of these firms providing a source of employment (see the next section), came to form a common theme in the political manifestoes. The Conservative October 1974 manifesto featured a dedicated section on Small Businesses in which this 'backbone of British enterprise' is described as 'immensely important to the economic life of Britain and to future industrial growth'. From the mid-1970s, the language of the manifestoes repeatedly associates SMEs with economic growth, whether through references to them as 'the seedcorn of the economy' and 'the seedcorn of Britain's prosperity’ (Conservative, 1992, 1997) or forming part of plans for industrial renewal (e.g. Liberal, 1979; Labour 1992). Irrespective of political and economic context, this characterisation of SMEs as central to the economy and to economic growth has become common across all three political parties (e.g. remaining 'the backbone of our economy', Labour, 2015), for some commentators reflecting the appropriation of SMEs by 'the politics of economic growth' (Fuller, 2006: 2).

By the time of the 1979 General Election, policy proposals were beginning to engage with the potential for SMEs in tackling problems of high inflation and unemployment owing to their lack of concentrated market power and typically high labour-intensity (Bannock, 1981). The Conservative government elected in 1979 oversaw a credit-inspired boom that saw the stock of SMEs expand significantly throughout the 1980s and early 1990s (Hughes, 2008) and the development of high profile initiatives such as the Training and Enterprise Councils (Huggins, 1997). This period is often discussed in terms of neoliberalism and the manifestoes tied SMEs to key areas of neoliberal policymaking, including financialisation (SMEs characterised as struggling to access finance, see below), deregulation and market liberalisation (SMEs characterised as over-burdened by regulation, see below) but also individual freedoms and the retreat of the state in terms of an enterprise culture and self-employment (though this was more clearly related to entrepreneurship and business start-up than SME policies). While ideological 
differences between the mainstream parties appeared stark, especially in terms of state intervention, contemporary commentators noted that 'Support for small firms is that rara avis of industrial policy - something which commands support across all the major parties' (Watkins et al., 1982: 1).

By 1997, the traditional Conservative reputation for economic competence was tarnished by the failed Poll Tax and a troubled economy, experienced especially harshly among SMEs (Bank of England, 1992) and with a substantial decline in SMEs numbers (Hughes, 2008). Labour, having implemented significant changes under Tony Blair, claimed that 'Support for small businesses will have a major role in our plans for economic growth' (Labour, 1997). Forming their first government in 18 years, Labour developed an increasing interest in self-employment and SMEs shaped by their focus on regional development, including help for disadvantaged groups and communities (Beresford, 2015; Huggins and Williams, 2009; Huggins et al., 2014). In this way, new policy areas were brought within the scope of SME policy with these businesses, and entrepreneurship more generally, seen as a potential solution to a range of economic and societal challenges. The Conservatives tied their SME proposals to promoting the 'right values', while the Liberals continued to develop SME policies in a range of specific areas and industries including supporting fisheries and local economies. While this broader sense of the implications of SME policy became commonplace, the 2010 and 2015 General Elections were dominated by the 2008 economic crash and a lack of confidence in the financial sector. In the manifestoes, access to finance by SMEs gained renewed attention, linked to prominent concerns with improving the banking sector.

Across these periods of significant economic, social and political change, ideological shifts and differences between the main political parties, our analysis identifies an increasing amount of attention paid to SMEs in political manifestoes, as demonstrated in Table 2. Three significant characterisations of SMEs emerge from our analysis: having the potential for growth, 
struggling to access finance and being over-burdened by regulation. It is these characterisations and how they developed over time that we now discuss, taking each theme in turn.

\begin{tabular}{|c|c|c|c|c|c|}
\hline Year & Party & SME & Growth & Finance & Regulation \\
\hline \multirow[t]{3}{*}{1964} & Con & & & & \\
\hline & $\mathrm{Lab}$ & $\mathbf{s}$ & & & \\
\hline & Lib & $\mathbf{S}$ & & & \\
\hline \multirow[t]{3}{*}{1966} & Con & $\mathbf{S}$ & G & & \\
\hline & $\mathrm{Lab}$ & & & & \\
\hline & Lib & & & & \\
\hline \multirow[t]{3}{*}{1970} & Con & $\mathbf{S}$ & & & $\mathbf{r}$ \\
\hline & $\mathrm{Lab}$ & & & & \\
\hline & Lib & $\mathbf{S}$ & & f & \\
\hline \multirow[t]{3}{*}{1974} & Con & $\mathbf{S}$ & G & & \\
\hline & $\mathrm{Lab}$ & & & & \\
\hline & Lib & & & & \\
\hline \multirow[t]{3}{*}{1974} & Con & $\mathbf{S}$ & & $\mathbf{F}$ & $\mathbf{r}$ \\
\hline & $\mathrm{Lab}$ & & & & \\
\hline & Lib & & & & \\
\hline \multirow[t]{3}{*}{1979} & Con & $\mathbf{S}$ & G & & $\mathbf{R}$ \\
\hline & $\mathrm{Lab}$ & $\mathbf{S}$ & $\mathbf{G}$ & & \\
\hline & Lib & $\mathbf{S}$ & $\mathbf{G}$ & & \\
\hline \multirow[t]{3}{*}{1983} & Con & $\mathbf{S}$ & $\mathbf{G}$ & $\mathbf{F}$ & $\mathbf{R}$ \\
\hline & $\mathrm{Lab}$ & $\mathbf{S}$ & & & \\
\hline & Lib & $\mathbf{S}$ & G & $\mathbf{F}$ & $\mathbf{R}$ \\
\hline \multirow[t]{3}{*}{1987} & Con & $\mathbf{S}$ & $\mathbf{G}$ & & \\
\hline & $\mathrm{Lab}$ & & & & \\
\hline & Lib & $\mathbf{S}$ & G & $\mathbf{F}$ & $\mathbf{r}$ \\
\hline \multirow[t]{3}{*}{1992} & Con & $\mathbf{S}$ & $\mathbf{G}$ & $\mathbf{F}$ & $\mathbf{r}$ \\
\hline & $\mathrm{Lab}$ & $\mathbf{S}$ & & f & \\
\hline & Lib & $\mathbf{S}$ & & $\mathbf{F}$ & $\mathbf{r}$ \\
\hline \multirow[t]{3}{*}{1997} & Con & $\mathbf{S}$ & G & & $\mathbf{R}$ \\
\hline & Lab & $\mathbf{S}$ & g & & $\mathbf{r}$ \\
\hline & Lib & $\mathbf{s}$ & g & $\mathbf{F}$ & $\mathbf{R}$ \\
\hline \multirow[t]{3}{*}{2001} & Con & $\mathbf{S}$ & g & & $\mathbf{R}$ \\
\hline & $\mathrm{Lab}$ & $\mathbf{S}$ & & & $\mathbf{R}$ \\
\hline & Lib & $\mathbf{S}$ & & & $\mathbf{R}$ \\
\hline \multirow[t]{3}{*}{2005} & Con & $\mathbf{S}$ & & & $\mathbf{R}$ \\
\hline & $\mathrm{Lab}$ & $\mathbf{S}$ & $\mathbf{g}$ & $\mathbf{F}$ & $\mathbf{r}$ \\
\hline & Lib & $\mathbf{S}$ & $\mathbf{G}$ & & $\mathbf{R}$ \\
\hline \multirow[t]{3}{*}{2010} & Con & $\mathbf{S}$ & $\mathbf{g}$ & $\mathbf{F}$ & $\mathbf{R}$ \\
\hline & $\mathrm{Lab}$ & $\mathbf{S}$ & g & $\mathbf{F}$ & $\mathbf{r}$ \\
\hline & Lib & $\mathbf{s}$ & & & \\
\hline \multirow[t]{3}{*}{2015} & Con & $\mathbf{S}$ & & $\mathbf{F}$ & $\mathbf{R}$ \\
\hline & $\mathrm{Lab}$ & S & G & $\mathbf{F}$ & $\mathbf{R}$ \\
\hline & Lib & $\mathbf{s}$ & & $\mathbf{F}$ & $\mathbf{R}$ \\
\hline
\end{tabular}

Table 2. Presence of themes in manifestoes.

Note: upper case indicates where SME/synonym (S) receives a heading or where coded characterisation (in relation to growth potential, G, access to finance, F, or burdens of regulation, R) receives clear, explicit attention. Lower case indicates mention of SMEs (s) or a less detailed or indirect characterisation ( $\mathrm{g}$, f or $\mathrm{r}$ ). 
Since the late 1960s and early 1970s, SMEs have been associated with the potential to grow and thereby provide economic growth and renewal. Irrespective of SME owners' desire to 'conform to the idea of growth - almost as a moral imperative' (Golby and Johns, 1971: 5), politicians began to emphasise their potential impact on unemployment, for example 'if all Britain's small firms took on one extra employee' (Expenditure Committee, 1978). Within a general association of SMEs and growth, of interest to politicians has therefore been the potential for SME growth to contribute to job creation (Atkinson and Storey, 1994; Nightingale and Coad, 2013). Much of the increase in government intervention post-Bolton can be associated with efforts to help SMEs grow (Beesley and Wilson, 1981), a level of initiatives that touched 3000 by 2006/7 (Public Accounts Committee, 2007).

In the economic crises that set the scene for the 1979 General Election, with the country facing increasing unemployment and 'economic decay' (Liberal, 1979), the link between SME growth and job creation became increasingly important. The incumbent Labour Government promised the continuation of the small firms employment subsidy (paying small manufacturing firms for jobs created) and proposed returning jobs to the inner-cities by stimulating the development of SMEs. The soon-to-be-elected Conservatives asserted explicitly that 'The creation of new jobs depends to a great extent on the success of smaller businesses'. For the Liberals, the link was more implicit but SMEs, and positive discrimination in their favour, was still associated with job creation.

The idea that SMEs were responsible for a disproportionately high number of jobs had gained increased attention with the 1979 publication of Birch's influential study. Birch reported that two-thirds of net new jobs created, in a sample of 5.6 million US businesses (1969-1976), were in firms employing twenty or fewer people (Birch, 1981). In 1984 Birch was invited to a job 
generation conference sponsored by the Department of Trade and Industry. The conference reflected the contrary evidence that had begun to emerge around the role of SMEs in creating new jobs and an increasing questioning of Birch's findings (Ganguly, 1985; Hirschberg, 1999). Exploring the impact of SMEs as job creators in the UK, Storey and Johnson (1987: 41) conclude that '...over a decade half the jobs created in every 100 small firms occur in the four firms which grow fastest.' Similar findings have been reported from the CBR studies, for example in Cosh and Hughes (1996) and Bullock et al (2000). More recently, Anyadike-Danes et al. (2015) highlight the importance of a very small number of 'extraordinary prolific job creators' (2015: 22). Research has therefore emphasised the role played not by the broad category of SMEs but by a minority of firms driving a disproportionate amount of job creation (Henrekson and Johansson, 2010).

The problematic nature of claims that SMEs, rather than a minority of firms, are responsible for a disproportionate amount of net job creation has been widely discussed. However, in the manifestoes, characterising SMEs in these terms has persisted and SME policies have often followed this characterisation, not only in terms of the rationales presented but the details of the policies themselves. While a few policies targeted key sectors such as manufacturing, the focus on 'More Small Firms' (Conservative, 1983) or 'Backing Small Business' (Liberal, 1987) continued to propose measures relating to removing general obstacles affecting all SMEs rather than attempts to target the small proportion of firms responsible for a disproportionate amount of net job creation. For example, while Labour have generally had less to propose in this area, both Conservatives and Liberals have frequently suggested SME job creation could be supported through reductions in taxation, access to public procurement and the areas of access to finance and burdens of regulation discussed below. These types of proposal tend not discriminate amongst SMEs nor address how to support the limited number of potentially high growth firms. 
Where SME policy in the 1980s focused largely on creating more SMEs, the 1988 DTI white paper The Department for Enterprise marked a move towards improving the quality of SMEs. In setting out an Enterprise Initiative this paper shifted attention 'to concentrate resources on improving the competitiveness of small and medium-sized firms' (Wren, 1996: 185; see also Greene et al., 2007; North et al., 1997). By the 1992 General Election, all three parties were making manifesto commitments concerning advisory and support services, building on earlier schemes such as the Small Firms Service and Business Development Service and leading to the expansion of more intensive support through government grants for accessing external consultancy (Bennett, 2012). Business Growth Training, for example, targeted support for 'smaller' firms (defined as fewer than 500 employees), providing financial support to access training and improve performance.

Government white papers included proposals to target high growth firms (e.g. DTI, 1994, 1995; see Smallbone, 1997) on the basis that 'Small firms [...] are a major source of job creation' (DTI, 1994: 12). Business Link (a state-funded 'one stop shop' for business support, proposed and developed in the manifestoes of all three parties) therefore aimed to help more small firms to grow into medium and large businesses, representing a shift from focusing primarily on startups to existing businesses (Priest, 1999). Business Link's Personal Business Advisors were instructed to target growth-oriented firms (Smallbone, 1997), in addition to Business Link's more general SME focus (defined by employment numbers). However, Forte (2011) recounts his personal experience that there was a lack of clarity on how to define or identify these businesses and this contributed to a more general variability of provision (Bennett and Robson, 2004).

Having the potential to grow is an important characterisation of SMEs throughout the manifestoes but, as Kiviluoto (2013) argues, business growth is not part of the everyday realities of running an SME for many owner-managers. The majority of firms do not grow in 
size but are, for roughly half of all new businesses, likely to fail within the first four years (Storey, 2011; see also Coad et al., 2013). The characterisation, apparent in the manifestoes, of SMEs as having growth potential is therefore wide of the mark, contraction or exit appears to be the most likely outcome over the longer-term (Anyadike-Danes et al., 2015). Further, as Shane (2009: 142) argues, most business founders are not establishing their business in order to grow them and create jobs but, rather, as 'wage-substitution businesses' (see also, Scase and Goffee, 1982; Sloan and Chittenden, 2006). Even during the 1980s, the 'age of the small business owner' (Scase and Goffee, 1987: 17), attitudes towards business growth remained mixed (Hakim, 1989; Scase and Goffee, 1987; Storey, 1989) and varied by firms' size (Cosh and Hughes, 1994). Perhaps most disappointingly for the politicians who pin their hopes for job generation on SMEs, responses to the Small Business Research Trust survey across the 1990s and early 2000s indicate that SME owners did not view business growth in terms of providing employment, preferring to grow turnover and profits rather than headcounts (SBRT, no date; also see Gibb, 2000; Greene et al., 2004)

Characterising SMEs, generally, as having the potential to grow and create jobs may prove popular in manifestoes but seems to bear only limited resemblance to the portrayal of SMEs in the research literature. It is apparent that some SMEs have the ambition and ability to grow and a handful prove extremely successful at creating new jobs. It cannot be said, however, that the performance of these few firms provides a helpful model on which to base a wider characterisation of SMEs or their potential role in the economy. A more accurate characterisation for a majority of SMEs would reflect an ambivalent attitude towards growth, especially in respect of jobs, from owner-managers for whom business contraction or exit appear to be the most likely outcome over the long-term. 
There have been long-standing and persistent concerns raised in relation to the availability of finance for SMEs since at least 1931 when the Macmillan Committee reported difficulties for small firms obtaining long-term capital (Macmillan, 1931). The so-called Macmillan gap (Frost, 1954), implying a market failure in terms of provision, is perceived as harming not only the daily operation of SMEs but to act as a brake on their business growth: firms are not able to invest and thereby expand. These concerns are reflected in UK political manifestoes where SMEs are characterised as facing problems in accessing external finance. While the Liberals in 1970 highlighted the 'credit squeeze' among 'very heavy burdens' on SMEs, the Conservatives in October 1974 argued that 'Small businesses often face the problem of longterm finance' and committed to setting up an enquiry to investigate. Labour, after winning this election, set up the Wilson Committee which published a 1979 report that identified some supply side problems in SME finance whilst acknowledging that many of the relative difficulties in accessing finance relate to the higher costs and risks of providing finance to these firms (Wilson, 1979).

In the 1980s, finance was tied to the concerns with SME growth discussed above, with both the Conservative and Liberal parties promising to extend a Business Start-Up Scheme to boost the numbers and the growth of SMEs by providing tax relief for investors. By the 1992 General Election, all three main parties were promising policy extensions or innovations to boost SMEs' access to finance, with Conservatives and Labour offering special conditions for 'inner-city areas' and 'women and ethnic minority' businesses respectively. More recently, the characterisation of SMEs as credit-constrained returned to prominence as part of political responses to the financial crisis when the availability of bank lending and other forms of finance was reduced, particularly for firms with high demands or perceived as otherwise risky (Fraser et al., 2013). In 2010, the Conservatives promised 'more diverse forms of affordable credit for 
small businesses [through] a national loan guarantee scheme' on the basis that 'lack of access to credit remains a problem, especially for SMEs'. The Labour Party promised to 'create a new Small Business Credit Adjudicator with statutory powers ensuring that SMEs are not turned down unfairly when applying to banks for finance.' This continued into 2015 when, for example, Labour argued that the '...long-standing problems of our banking system mean that too many small and medium-sized businesses cannot get the finance they need to invest and grow.'

The manifestoes therefore tend to identify supply-side problems, an unwillingness on the part of financial institutions to provide finance to SMEs, and policies have followed. For example, in the mid-1970s the National Enterprise Board contained a remit for providing equity and loan capital to SMEs seeking funds at the lower end of the market (Lonsdale, 1997). As with schemes that would follow, such as the Business Expansion Scheme and various incarnations of loan guarantee schemes, the significance of positive impacts from such interventions has been called into question (Parker, 2002; Storey, 1994). The Enterprise Finance Guarantee scheme, for example, established in 2009 to replace the Small Firms Loan Guarantee with a rationale 'targeted at small businesses affected by lack of security that would otherwise not be able to access conventional bank loans' represented up to just $2 \%$ of the term loan market for SMEs (Allinson et al., 2013: v).

Clearly, firms operate within a wider context that can influence business conditions (Curran, 1987). During times of recession, when available finance may be reduced generally, ‘...lending institutions appear to use firm size as their primary lending criterion, with micro-business in particular being restricted in its access to capital' (Cowling et al., 2012: 794). However, examinations of the availability of bank credit during the 1980s (Cosh and Hughes, 1994; DTI, 1991) found that few difficulties were faced in obtaining necessary finance for investment. An analysis of manufacturing and business services firms, employing up to 500 people, in the mid- 
to late-1990s suggested that 'few firms face a problem in obtaining all of their desired external capital' (Cosh et al., 2009a: 1531). Based on data gathered in 2005, Freel et al. (2012) also report the vast majority of applicants for credit being approved. SMEs that are 'high-growth' or pursuing innovative lines of business, potentially heightening informational asymmetries (and, perhaps, the perception of risk), may be more likely to report significant finance problems (Ennew and Binks, 1996; Freel, 2007; BIS, 2012; Baldock, 2016). However, the accumulation of evidence throughout our period of analysis suggests that the supply-side problems repeated in the manifestoes concerning the broad SME category, and many of the finance-related policies that have followed them, is over-stated.

Provision of finance is also subject to demand and desire for external finance is not widespread among SME owners. Pecking order theory (Myers, 1984) indicates that firms use internal funds before seeking external sources, meaning that not all firms will seek bank loans and very few will sacrifice a share of ownership for equity investment (Cosh et al., 2009a; Freel, 2007; Parker, 2002; Wilson, 1979). During periods of heightened uncertainty demand is likely to decline further, although it is worth noting that this was a more significant issue in the recession following the financial crisis than, for example, the recession of 1991 (Cosh et al., 2009b). BIS (2012) cites data for SMEs with turnover below $£ 1 \mathrm{~m}$ as being net depositors to the tune of $£ 3.7 \mathrm{bn}$ at the end of 2007. A more accurate characterisation of SMEs, albeit still an overgeneralisation, may therefore be a lack of desire for external finance, especially equity finance (accepting a role for discouragement, Fraser, 2014). Overlooking demand-side perspectives on accessing finance suggests a contributing factor for why supply-side-oriented policy measures based on a mischaracterisation of the SME category are likely to fail. 
Regulation has figured prominently in political discourse around SMEs. While initially focused on taxation and largely the preserve of the Conservatives in the 1970s and 1980s, since the early 1990s all three mainstream parties have included proposals for reducing or reforming regulations, including to limit the impacts on SMEs. The 1979 Conservative manifesto provides a clear example of how this agenda developed to address perceived barriers, detailing the need to reduce taxation, form-filling and 'amend laws such as the Employment Protection Act where they damage smaller businesses - and larger ones too - and actually prevent the creation of jobs'.

This policy agenda developed as part of broader market liberalisation. It won influential support with the work of Djankov (e.g. Djankov et al., 2002, Djankov, 2009) which argued that the costs of regulation present a burden on entrepreneurs and that the creation of a low regulation economy, principally through deregulation, would therefore encourage business start-up and growth. However, Capelleras et al. (2008: 691) explain that those studies providing evidence for the Djankov view draw upon official data that exclude non-registered businesses. Such studies tend towards a macroeconomic focus and often draw inferences from data reflecting relatively large SMEs, overlooking the experiences of the more numerous very small firms within the SME category. These macroeconomic findings are not clearly reflected in the reported firm-level experiences of SMEs owners themselves. When asked about the main obstacles to the success of their businesses, owners express a range of views over time and reflecting other influences, but regulation tops the tables infrequently (see e.g. SBRT, no date).

Nonetheless, the manifestoes and subsequent policies (and advisory bodies such as the Better Regulation Task Force) introduced the idea of 'better' regulation alongside deregulation. After 18 years in government, the 1997 Conservative manifesto claimed they had 'abolished over a 
thousand regulations'. Campaigning for re-election they explained that, if they were to be reelected, new regulations would 'only be introduced if it is clear that their benefits exceed their costs and they do not place an undue burden on a small firm'. However, the Conservatives were defeated by a rebranded Labour party that promised to 'cut unnecessary red tape' and, after four years in government, later proposed that 'Regulation should be introduced, where it is necessary, in a light-touch way [they would also] examine opportunities to put time limits on regulations, deregulate by secondary legislation, and offer help to small firms' (Labour, 2001).

Such talk has been a consistent feature of UK political manifestoes up to and including the General Election in 2015. The Conservative 2015 manifesto promised to 'cut a further $£ 10$ billion of red tape over the next Parliament through our Red Tape Challenge and our One-InTwo-Out rule'. Regulation therefore continues to be presented as a quantitative problem: the more regulations cut, the easier growing a business becomes and this can be assessed through a cost-benefit analysis (BIS, 2015). However, regulations, and how they are interpreted, will affect businesses in different ways owing to differences in firm size, age and sector, competitive conditions, degrees of enforcement and the responses of others in the firm's external and internal environments (Arrowsmith et al., 2003; Kitching, 2006; Hart and Blackburn, 2005). Many regulations are also likely to not be relevant for particular SMEs. For example, an audit of government regulatory reform in the 2010-2015 Parliament found that $90 \%$ of the claimed cost reductions could be attributed to just ten regulatory decisions (NAO, 2016). This may explain why studies have repeatedly shown that, while business-owners complain about regulation in general, relatively few can provide specific instances of where their business has been affected by particular regulations (Edwards et al., 2004). Further, this approach fails to account adequately for those owner-managers who describe regulation as benefiting their business, not only in terms of creating a stable trading environment, establishing and protecting 
markets (DTI, 1985) but also by supporting a firm's development of management capabilities and formal processes (Kitching et al., 2015; Scott et al. 1989).

The characterisation of SMEs as over-burdened by regulation remains influential. Yet, while bureaucracy is often a cost of doing business, research evidence questions whether it is one of the major challenges facing SMEs, sufficient to justify the attention it receives. Consequently, for SMEs the relevance and potential impact of deregulation and regulatory reform may be limited.

\section{Discussion}

The concerns with SMEs in the UK political manifestoes from 1964-2015 emerge from a relative absence prior to the 1970 s to a focus on the quantity of businesses in the 1980 s, to quality in the 1990s and then to a more balanced approach, widening the policy focus to attend to social issues such as marginalised communities. These broad trends are recognisable from the analysis of previous studies of SME policy such as Greene et al. (2007). Our analysis has sought to explore the underlying themes in political discourse throughout this period by analysing the key ways in which the category of SME has been characterised. These characterisations are important because they create the impression of common concerns and challenges within the SME category, a problem definition that governments then seek to address (Weiss, 1989).

The three main UK political parties, despite their different ideological roots, have arrived at similar characterisations of SMEs during the period of analysis. SMEs have come to be characterised as having the potential for growth, struggling to access finance and being overburdened by regulation. This has led to similar SME policy proposals in the manifestoes and a lack of rigorous debate in this area of policymaking. This is despite evidence that SME policies have often failed to achieve their aims (Bridge, 2010), suffering displacement and deadweight 
effects (Curran and Storey, 2002; Nightingale and Coad, 2016; Wren, 1996), insufficient coordination (Huggins and Williams, 2009; Turok, 1997) and a tendency to overlook available research evidence (Arshed et al., 2014; Blackburn and Schaper, 2012; Curran and Storey, 2002).

The creation of a distinct SME category has clear value for politicians and policymakers, simplifying complex heterogeneity (Curran and Blackburn, 2000; Leyshon, 1982; Massey, 2006) but also establishing a target for policy interventions by creating a constituency to address and to fight for (Stone, 1989). However, this categorisation is problematic because it homogenises and obscures differences that may be important for understanding how firms operate, their different goals and the different challenges they encounter. This has been acknowledged periodically and some policies have targeted subsections of the SMEs category, although this has tended to be part of supporting particular sectors of the economy such as manufacturing. A recent, high profile report called for removing or revising the SME term and for a focus on high-growth businesses (Coutu, 2014) and this appears to have been listened to in a subsequent green paper (HM Government, 2017). However, although the evidence supporting this move has been well-recognised for a long time (e.g. DTI, 1994, 1995) it has often not been reflected in policymaking and the jobs generated by those firms labelled as high growth or scale ups are frequently attributed to the much broader SME category throughout our period of analysis. This is then frequently used as a rationale for broader SME policymaking.

We have demonstrated how the characterisation of the SME category in political discourse contradicts empirical evidence. Many of the firms grouped together by this statistical convenience are ambivalent about business growth, use internal funds before seeking external sources (and, when external, to prefer debt-financing to equity financing) and are able to cope with regulation (with some studies suggesting the benefits of regulation, especially where they 
do pursue growth). If the businesses homogenised under the SME category are significantly mischaracterised and the differences between them obscured, then policy in this area will continue to be ineffective. If seeking primarily to support job creators, addressing the concerns of the broad category of SMEs may itself be misguided given the disproportionate contribution of a handful of SMEs.

The characterisation that has come to dominate discussion of the SME category in the manifestoes of the three main UK political parties is therefore a fundamental flaw in the development of SME policy. Failing to engage fully with empirical evidence has created a mischaracterisation that squeezes out the everyday experience of the majority of businesses. Policy developed to respond to the perceived challenges facing the firms in the SME category can only be developed effectively through a robust and rigorous understanding of these firms and their (variable) characteristics. A lack of rigorous, informed debate has contributed to failures to learn and develop in SME policymaking, resulting in a recycling of ineffective policies (Blackburn and Schaper, 2012; Bridge, 2010; Greene et al., 2007; Huggins and Williams, 2009). Evidence-based debate is important in achieving useful categories of business and accurate characterisations from which policy can be rigorously developed; our analysis suggests this has not yet happened in SME policymaking.

\section{Conclusion}

Analysis of political discourse in the UK in the form of General Election manifestos from 19642015 suggests the existence of a broadly-defined SME category that has been mischaracterised as having the potential for growth, struggling to access finance and being over-burdened by regulation. While others have rightly identified the ineffective development, delivery and coordination of policy initiatives in this area, we have sought to contribute to this debate by arguing that the problematic nature of how SMEs are categorised and characterised creates a 
more fundamental problem. If the businesses homogenised under labels such as SME are significantly misrepresented and the differences between them are obscured, then it is not, for example, the coordination of policies that needs greatest attention but the assumptions underlying these policies. Importantly, these assumptions now appear shared across the mainstream political parties in the UK, lacking critical debate and new ideas.

Our analysis has several limitations. Focus on SMEs within political manifestoes inevitably foregrounds these issues relative to wider considerations and risks placing too much emphasis on one area of policy. Further, while manifestoes are a valuable focus for analysis they are only a part of wider political debates. In choosing to cover a broad sweep of time we have prioritised breadth, trading-off depth as each aspect we have highlighted constitutes a field in itself. Nevertheless, the broader perspective offered in this paper does offer an overview of how SMEs are categorised and characterised to raise significant concerns about fundamental flaws in the assumptions underlying SME policymaking, suggesting a potential cause for its lack of effectiveness.

Future research is needed to further explore the impact and implications of how SMEs are categorised and characterised for SME policy, amid a wider range of political discourse as well as in different cultural, political and economic contexts. While we focus on SME policy, there are also potential questions for problem definition in terms of the characterisation of entrepreneurs and therefore for entrepreneurship policy (see e.g. Jones and Spicer, 2005). There is a continuing need to robustly evaluate policy interventions but also the underlying assumptions that underpin them. Most importantly, there is a need to develop serious and public debate over SME policy through the production and promotion of rigorous empirical evidence that is available and promoted to stakeholders. 


\section{References}

Allinson G, Robson P and Stone I (2013) Economic evaluation of the enterprise finance guarantee $(E F G)$ scheme. Department for Business Innovation \& Skills: London. URN 13/600.

Anyadike-Danes M, Hart M and Du J (2015) Firm dynamics and job creation in the United Kingdom: 1998-2013. International Small Business Journal 33(1): 12-27.

Arrowsmith J, Gilman MW, Edwards P and Ram M (2003) The impact of the National Minimum Wage in small firms. British Journal of Industrial Relations 41(3): 435-456.

Arshed N, Carter S and Mason C (2014) The ineffectiveness of entrepreneurship policy: is policy formulation to blame? Small Business Economics 43(3): 639-659.

Atkinson CL (2015) The power of "small business" as pending narrative: an ideograph in UK politics 2004-2013. Social Semiotics DOI: 10.1080/10350330.2015.1045164

Atkinson J and Storey D (1994) Small firms and employment. In: Atkinson J and Storey D (eds) Employment, the small firm and the labour market. London: Routledge, pp. 1-27

Baldock R (2016) An assessment of the business impacts of the UK's Enterprise Capital Funds. Environment and Planning C: Government and Policy 34(8): 1556-1581.

Bank of England (1992) Banking Act report for 1991/92. ISSN:0308-5279.

Bannock G (1981) The Economics of Small Firms: Return from The Wilderness. Oxford: Basil Blackwell.

Bara J (2005) A question of trust: Implementing party manifestos. Parliamentary Affairs 58(3): 585-599.

Beesley ME and Wilson PEB (1981) Government aid to small firms in Britain. In: Gorb P, Dowell P and Wilson P (eds) Small Business Perspectives. London: Armstrong Publishing / London Business School, pp.254-308.

Bennett R (2008) SME policy support in Britain since the 1990s: what have we learnt? Environment and Planning C: Government and Policy 26(2): 375-397.

Bennett R (2012) Government advice services for SMEs: some lessons from British experience. In: Government SMEs and Entrepreneurship Development: Policy, Practice and Challenges Blackburn R and Schaper M (eds). Gower, Farnham, pp.185-198.

Bennett R (2014) Entrepreneurship, Small Business and Public Policy: Evolution and Revolution. Abingdon: Routledge.

Bennett R and Robson P (2004) Support services for SMEs: Does the 'franchisee' make a difference to the Business Link offer? Environment and Planning C: Government and Policy 22(6): 859-880.

Beresford R (2015) New Labour and enterprise policy: Continuity or change? Evidence from general election manifestos. British Politics 10(3): 335-355. 
Birch DL (1981) Who creates jobs? The Public Interest Fall 1981: 3-14.

BIS (2012) SME Access to External Finance. Department for Business Innovation and Skills: BIS Economics Paper No. 16, URN 12/539.

BIS (2015) Better Regulation Framework Manual. Available at: https://www.gov.uk/government/publications/better-regulation-framework-manual (accessed: 19 January 2017).

BIS (2016) Business population estimates for the UK and regions 2016. Available at: https://www.gov.uk/government/uploads/system/uploads/attachment_data/file/559219/bpe_2 016_statistical_release.pdf (accessed: 30 January 2017).

Blackburn R and Schaper M (2012) Introduction. In: Government SMEs and Entrepreneurship Development: Policy, Practice and Challenges Blackburn R and Schaper M (eds). Gower, Farnham, pp.1-15.

Bolton JE (1971) Small Firms: Report of the Committee of Inquiry. Cmnd 4811, London: Department of Trade and Industry, HMSO.

Bridge S (2010) Rethinking enterprise policy. Basingstoke: Palgrave.

Capelleras JL, Mole KF, Greene FJ and Storey DJ (2008) Do more heavily regulated economies have poorer performing new ventures? Evidence from Britain and Spain. Journal of International Business Studies 39(4): 688-704.

Carter S, Mason C and Tagg S (2009) Perceptions and experience of employment regulation in UK small firms. Environment and Planning C: Government and Policy 27(2) 263-278.

Coad A, Frankish J, Roberts RG and Storey DJ (2013) Growth paths and survival chances: an application of Gambler's Ruin theory. Journal of Business Venturing 28:615-632.

Cosh A and Hughes A (1994) Size, financial structure and profitability: UK companies in the 1980s. In: Hughes A and Storey DJ (eds) Finance and the small firm. Routledge, London, pp.18-63.

Cosh A and Hughes A (1996) The changing state of British enterprise: growth, innovation and competitive advantage in small and medium sized firms 1986-1995. Cambridge: ESRC Centre for Business Research.

Cosh A and Hughes A (1998) Enterprise Britain: Growth, Innovation and Public Policy in the Small and Medium Sized Enterprise Sector 1994-1997. Cambridge: ESRC Centre for Business Research.

Cosh A, Cumming D and Hughes A (2009a) Outside entrepreneurial capital. The Economic Journal 119(540): 1494-1533.

Cosh A, Hughes A, Bullock A and Milner I (2009b) SME finance and innovation in the current economic crisis. Cambridge: ESRC Centre for Business Research.

Coutu S (2014) The Scale-Up Report. Available at: http://www.scaleupreport.org/ (accessed 02 February 2017). 
Cowling M, Liu W and Ledger A (2012) Small business financing in the UK before and during the current financial crisis. International Small Business Journal 30(7): 778-800.

Curran J (1987) Small enterprises and their environments. Kingston: Kingston Polytechnic Small Business Research Unit

Curran J (2000) What is small business policy in the UK for? Evaluation and assessing small business policies. International Small Business Journal 18(3): 36-50.

Curran J and Blackburn R (2000) Panacea or white elephant? A critical examination of the proposed new small business service and response to the DTI consultation paper Regional Studies 34(2): 181-189.

Curran J and Stanworth J (1982) Bolton ten years on - a research inventory and critical review. In Stanworth J, Westrip A and Watkins D (eds) Perspectives on a Decade of Small Business Research: Bolton Ten Years On. Aldershot: Gower, pp. 3-28.

Curran J and Storey DJ (2002) Small business policy in the United Kingdom: the inheritance of the Small Business Service and implications for its future effectiveness. Environment and Planning C: Government and Policy 20(2): 163-177.

Dannreuther C and Perren L (2013) The Political Economy of the Small Firm London: Routledge.

Djankov S (2009) The regulation of entry: a survey. World Bank Research Observer 24(2): 183-203.

Djankov S, La Porta R, Lopez-de-Silanes F and Shleifer A (2002) The regulation of entry. Quarterly Journal of Economics 117(1): 1-37.

DTI (1985) Burdens on Business. London: Department of Trade and Industry, HMSO.

DTI (1988) Department for Enterprise. London: Department of Trade and Industry, HMSO.

DTI (1991) Constraints on the growth of small firms. London: Department of Trade and Industry, HMSO.

DTI (1994) Competitiveness: Helping Business to Win. London: Department of Trade and Industry, HMSO.

DTI (1995) Competitiveness: Helping Smaller Firms. London: Department of Trade and Industry, HMSO.

Edwards P, Ram M and Black J (2004) Why does employment legislation not damage small firms? Journal of Law and Society 31(2): 245-265.

Ennew CT and Binks MR (1996) Banks and small businesses: an Anglo-Scottish comparison. In: Danson MW (Ed) Small firm formation and regional economic development. London: Routledge, pp. 81-98.

European Commission (2015) User Guide to the SME Definition. Luxembourg: Publications Office of the European Union. 
Finlayson, A (2007) From Beliefs to Arguments: Interpretive Methodology and Rhetorical Political Analysis. The British Journal of Politics and International Relations 9: 545-563

Forte E (2011) Intervention: The Battle for Better Business. Lulu.com.

Fraser S (2014) Back to borrowing? Perspectives on the 'arc of discouragement'. ERC White Paper No.8 Executive Summary. Enterprise Research Centre.

Fraser S, Bhaumik S and Wright M (2013) What Do We Know About The Relationship Between Entrepreneurial Finance and Growth? ERC White Paper No.4. Enterprise Research Centre.

Freel MS (2007) Are Small Innovators Credit Rationed? Small Business Economics 28(1): 2335 .

Freel M, Carter S, Tagg S and Mason C (2012) The latent demand for bank debt: characterizing “discouraged borrowers" Small Business Economics 38(4): 399-418.

Frost, R (1954). The Macmillan Gap 1931-53. Oxford Economic Papers 6(2): 181-201.

Fuller T (2003) If you wanted to know the future of small business what questions would you ask? Futures 35: 305-321.

Fuller T (2006) Guest editorial: Small business policy. Environment and Planning C: Government and Policy 24(1): 1-4.

Ganguly P (1985) United Kingdom Small Business Statistics and International Comparisons. London: Sage.

Gibb AA (2000) SME policy, academic research and the growth of ignorance, mythical concepts, myths, assumptions, rituals and confusions. International Small Business Journal 18(3): 13-35.

Gilman MW and Edwards PK (2008) Testing a framework of the organization of small firms: Fast-growth, high-tech SMEs. International Small Business Journal 26(5): 531-558.

Golby CW and Johns G (1971) Attitude and Motivation. Committee of Inquiry on Small Firms, Research Report no.7. London: HMSO.

Greene FJ, Mole KF and Storey DJ (2004) Does more mean worse? Three decades of enterprise policy in the Tees Valley. Urban Studies 41(7): 1207-1228.

Greene FJ, Mole KF and Storey DJ (2007) Three decades of enterprise culture: Entrepreneurship, economic regeneration and public policy. Basingstoke: Palgrave.

Hakim C (1988) Self-employment in Britain: recent trends and current issues. Work, Employment \& Society 2(4): 421-450.

Hart M and Blackburn R (2005) Labour regulation and SMEs: A challenge to competitiveness and employability? In: Marlow S, Patton D and Ram M (eds) Managing Labour in Small Firms. London: Routledge, pp.72-86. 
Henrekson M and Johansson D (2010) Gazelles as job creators: a survey and interpretation of the evidence. Small Business Economics 35(2): 227-244.

Hirschberg D (1999) The Job-Generation Controversy: The Economic Myth of Small Business. Armonk (NY): ME Sharpe.

HL Deb (12 February 2003) vol 644 cc126-7WA. Available at: http://hansard.millbanksystems.com/written_answers/2003/feb/12/small-and-medium-sizedenterprises\#S5LV0644P0_20030212_LWA_41 (accessed 02 February 2017).

HM Government (2017) Building Our Industrial Strategy. Available at: https://www.gov.uk/government/uploads/system/uploads/attachment_data/file/586626/buildin g-our-industrial-strategy-green-paper.pdf (accessed 02 February 2017).

Huggins R (1997) Training and Enterprise Councils as facilitators of a networked approach to local economic development: forms, mechanisms, and existing interpretations. Environment and Planning C: Government and Policy 15(3): 273-284.

Huggins R, Morgan B and Williams N (2015) Regional entrepreneurship and the evolution of public policy and governance: Evidence from three regions. Journal of Small Business and Enterprise Development 22(3): 473-511.

Huggins R and Thompson P (2014) Culture, entrepreneurship and uneven development: a spatial analysis. Entrepreneurship \& Regional Development 26(9-10): 726-752.

Huggins R and Williams N (2009) Enterprise and public policy: a review of Labour government intervention in the United Kingdom. Environment and Planning C: Government and Policy 27(1): 19-41.

Hughes A (2008) Entrepreneurship and innovation policy: retrospect and prospect. The Political Quarterly 79(s1): 133-152.

Jones C and Spicer A (2005) The sublime object of entrepreneurship. Organization 12(2): 223246.

Kirby D (2004) Guest editorial: Government and policy for SMEs in the UK. Environment and Planning C: Government and Policy 22(6): 775-777.

Kitching J (2006) A burden on business? Reviewing the evidence base on regulation and smallbusiness performance. Environment and Planning C: Government and Policy 24(6): 799-814.

Kitching J, Hart M and Wilson N (2015) Burden or benefit? Regulation as a dynamic influence on small business performance. International Small Business Journal 33(2): 130-147.

Kiviluoto N (2013) Growth as evidence of firm success: myth or reality? Entrepreneurship \& Regional Development 25(7-8): 569-586.

Laver M and Garry J (2000) Estimating Policy Positions from Political Texts. American Journal of Political Science 44(3): 619-634

Leyshon A (1982) The UK Government small business model - a review. European Small Business Journal 1(1): 58-66. 
Lonsdale C (1997) The UK equity gap: The failure of government policy since 1945. Aldershot: Ashgate.

Lundström A, Vikström P, Fink M, Meuleman M, Głodek P, Storey D and Kroksgård A (2014) Measuring the costs and coverage of SME and entrepreneurship policy: a pioneering study. Entrepreneurship Theory and Practice 38(4): 941-957.

Macmillan H (1931) Report of the Committee on Finance and Industry. Cmd 3897, London: HMSO.

Massey C (2006) A new conceptualisation of business development for SMEs: a focus on development potential. Environment and Planning C: Government and Policy 24(1) 37-49.

May T and McHugh J (2002) Small business policy: a political consensus? The Political Quarterly 73(1): 76-85.

NAO (2006) Supporting Small Business. London: National Audit Office. HC 962.

NAO (2016) The Business Impact Target: cutting the cost of regulation. London: National Audit Office. HC 236.

Nightingale P and Coad A (2013) Muppets and gazelles: political and methodological biases in entrepreneurship research. Industrial and Corporate Change 23(1): 113-143.

Nightingale P and Coad A (2016) Challenging assumptions and bias in entrepreneurship research. In: Landstrom H, Parhankangas A, Fayolle A and Riot P (eds) Challenging Entrepreneurship Research. London: Routledge, pp.101-128.

North J, Curran J and Blackburn R (1997) Quality standards and small firms: A policy mismatch and its impact on small enterprise. In: Deakins D, Jennings P and Mason CM (eds) Small Firms: Entrepreneurship in The Nineties. London: Paul Chapman, pp.112-126.

Parker SC (2002) Do banks ration credit to new enterprises? And should governments intervene? Scottish Journal of Political Economy 49(2): 162-195.

Priest SJ (1999). Business Link services to small and medium-sized enterprises: targeting, innovation, and charging. Environment and Planning C: Government and Policy 17, 177-194.

Public Accounts Committee (2007) Supporting Small Business. House of Commons Committee of Public Accounts, Eleventh Report of Session 2006-07. HC 262. London: The Stationery Office Limited.

Radcliffe CJ (1959) Committee on the working of the monetary system. London: HMSO, Cmnd 827.

Richard D (2008) Small Business and Government: The Richard Report. London: Conservative Party.

Rochefort DA and Cobb RW (1993) Problem definition, agenda access, and policy choice. Policy Studies Journal 21(1): 56-71. 
Royed T (1996) Testing the Mandate Model in Britain and the United States: Evidence from the Reagan and Thatcher Eras. British Journal of Political Science 26(1): 45-80.

SBRT [no date]. Quarterly Survey of Small Business in Britain 1985-2014. Available at: http://business-school.open.ac.uk/research/quarterly-survey\# (accessed 02 February 2017).

Scase R and Goffee R (1982) The Entrepreneurial Middle Class. London: Croom Helm.

Scase R and Goffee R (1987) The real world of the small business owner. London: Croom Helm.

Scott M, Roberts I, Holroyd G and Sawbridge D (1989) Management and Industrial Relations in Small Firms. Department of Employment Research Paper No.70. London: HMSO.

Shane S (2009) Why encouraging more people to become entrepreneurs is bad public policy. Small Business Economics 33(2): 141-149.

Sloan B and Chittenden F (2006) Fiscal policy and self-employment: targeting business growth. Environment and Planning C: Government and Policy 24(1): 83-98.

Smallbone D (1997) Selective targeting in SME policy: criteria and implementation issues. In: Deakins D, Jennings P and Mason CM (eds) Small Firms: Entrepreneurship in The Nineties. London: Paul Chapman, pp.127-140.

Stone DA (1989) Causal stories and the formation of policy agendas. Political Science Quarterly 104(2): 281-300.

Storey DJ (1989) Firm performance and size: Explanations from the small firm sectors. Small Business Economics 1(3): 175-180.

Storey DJ (1994) Understanding the small business sector. London: Routledge.

Storey DJ (2011) Optimism and chance: The elephants in the entrepreneurship room. International Small Business Journal 29(4): 303-321.

Storey DJ (2005) Entrepreneurship, small and medium sized enterprises and public policy. In: Acs ZJ and Audretsch DB (eds) International Handbook of Entrepreneurship Research. London: Springer, pp.473-511.

Storey DJ and Johnson S (1987) Are small firms the answer to unemployment? London: Employment Institute

Tomlinson, J.D. (1994) Government and the enterprise since 1900: the changing problem of efficiency. Oxford: Oxford University Press.

Turok I (1997) Disconnected Measures: European Structural Fund Support for Small Business. In: Deakins D, Jennings P and Mason CM (eds) Small Firms: Entrepreneurship in The Nineties. London: Paul Chapman, pp.141-161.

Wapshott R and Mallett O (2015) Managing Human Resources in Small and Medium-sized Enterprises. Abingdon: Routledge. 
Ward M and Rhodes C (2014) Small businesses and the UK economy. House of Commons Library (Economic Policy and Statistics) SN/EP/6078.

Watkins D, Stanworth J and Westrip A (1982) Editor's overview [sic]. In: Watkins D, Stanworth J and Westrip A (eds) Stimulating small firms. Aldershot: Gower, pp.1-6.

Weatherill B and Cope J (1969) Acorns to oaks: a policy form small business. London: Conservative Political Centre.

Weiss JA (1989) The powers of problem definition: The case of government paperwork. Policy Sciences 22(2): 97-121.

Wilson H (1979) The Financing of Small Firms, Interim Report of the Committee to Review the Functioning of the Financial Institutions. London: HMSO, Cmnd 7503.

Wren C (1996) Industrial Subsidies: The UK Experience. Basingstoke: Macmillan Press. 